\title{
Estimation of Dry Season Irrigation Water Abstraction in Lunsemfwa, Mulungushi, Mwomboshi, and Mkushi Subbasins from 2013 to 2017 in Zambia
}

\author{
Lamong Duke Tshenyego $(\mathbb{D}$, Kamuti Mulonda, and Isaac Nyambe Simate $(\mathbb{i D}$ \\ Department of Agricultural Engineering, University of Zambia, Lusaka, Zambia \\ Correspondence should be addressed to Lamong Duke Tshenyego; dukelamong@gmail.com
}

Received 6 February 2019; Revised 15 April 2019; Accepted 17 April 2019; Published 14 July 2019

Academic Editor: Gábor Kocsy

Copyright (C) 2019 Lamong Duke Tshenyego et al. This is an open access article distributed under the Creative Commons Attribution License, which permits unrestricted use, distribution, and reproduction in any medium, provided the original work is properly cited.

\begin{abstract}
Water abstraction depends on many variables that include the purpose for the abstraction, the location, the policies in place, and the type of water resources available for abstraction. The overall objective of this study was to estimate irrigation water abstraction from Mkushi, Mulungushi, Mwomboshi, and Lunsemfwa subbasins in Zambia. Reference evapotranspiration was determined using FAO ETo calculator and the results ranged from $6.84 \mathrm{~mm}$ /day to $7.02 \mathrm{~mm} /$ day. For this study the soils were set as described in the soil map of Zambia and put into the soil characteristic calculator to estimate their physical properties. The results estimate that a total maximum abstraction of $119,680,200 \mathrm{~m}^{3}$ was in 2013, and a minimum estimate of 74,951,400 $\mathrm{m}^{3}$ was in 2014. Wheat abstraction volumes (which were used to represent crops with higher water demand) were compared between catchments and significant differences exist when comparing Lunsemfwa catchment to Mkushi, Mulungushi, and Mwomboshi; thus there were no chances of similarity at an alpha level of 0.05. This means that Lunsemfwa catchment abstracted most irrigation water from 2013 to 2017 than the other three catchments as a result of having the largest proportion of irrigated area in the subbasin.
\end{abstract}

\section{Introduction}

Irrigation impact in Zambia depends on factors such as the level of demand and importantly on the prioritisation given to irrigation over hydropower production [1]. This is mostly the case in dry areas [2]. Agricultural irrigation is one of the global abstractors of water for approximately $70 \%$ of water in the world. It is projected that irrigated land in developing countries will increase by $27 \%$ in the next 20 years [3]. Water for irrigation is the only option to improve food production in low rain regions but it is affected by the changing weather conditions which may increase evapotranspiration and thus raise crop water requirement [4]. This also has posed some uncertainty about quantity and reliability of the supply [3], as irrigation can result in the reduction of upstream and downstream flows.

Irrigation requirement is closely related to crop water requirement. Crop water requirement together with effective rainfall also includes additional water for leaching of salts and compensation for other water losses [5].
The quantity of water to compensate for evapotranspiration losses from plant grown in a field is known as crop water requirement. It is normally assumed that the values of crop water requirement and evapotranspiration (ET) are identical [6]. Crop water requirement means the amount of water needed to be supplied to the crop for growth while crop evapotranspiration refers to the amount of water that is lost through evaporation and transpiration. Due to cost and difficulty in obtaining accurate field measurement ET is normally calculated using weather data. Many researchers have analyzed the fit of the various calculation methods in different locations. As an outcome of an Expert Consultation held in May 1990, the FAO Penman-Monteith method is now suggested as the standard method of calculating reference evapotranspiration (ETo) $[7,8]$. Reliable estimation of ET is important in that it helps determine the size of canals, pumps, and dams when designing water abstraction for irrigation [9].

In Zambia, the Mulungushi dam with a capacity of $2.60 \times 10^{8} \mathrm{~m}^{3}$ and the Mitta hills dam with a capacity of $6.79 \times 10^{8} \mathrm{~m}^{3}$ of water to generate hydropower [10] have 
TABle 1: Information used to run the AquaCrop model.

\begin{tabular}{|c|c|c|c|c|c|c|c|c|}
\hline \multicolumn{9}{|l|}{ IMPUT } \\
\hline \multirow{4}{*}{ Climate } & Temp.: & \multicolumn{6}{|c|}{ Taken from weather stations each month from 2013 to 2017} & \\
\hline & ETo: & \multicolumn{6}{|c|}{ From ETo calculator each month from 2013 to 2017} & \\
\hline & Rainfall: & \multicolumn{6}{|c|}{ Taken from weather stations each month from 2013 to 2017} & \\
\hline & $\mathrm{CO}_{2}:$ & \multicolumn{6}{|c|}{ Was left as default of model atmospheric $\mathrm{CO}_{2}$ concentration from $1902-2099$} & \\
\hline \multirow[t]{2}{*}{ Crop; } & Soybean & \multicolumn{6}{|c|}{ Growing Cycle; day 1 after sowing 2 May to Maturity: 25 July } & \\
\hline & Wheat & \multicolumn{6}{|c|}{ Growing Cycle; day 1 after sowing 2 May to Maturity: 29 August } & \\
\hline \multicolumn{2}{|c|}{ Management } & \multicolumn{6}{|c|}{ Determination of net irrigation water requirement } & \\
\hline \multirow{6}{*}{ Soil } & & \multirow{2}{*}{ thickness (m) } & PWP & FC & SAT & TAW & \multirow{2}{*}{ Ksat $(\mathrm{mm} / \mathrm{hr})$} & \multirow{2}{*}{ Soil Type } \\
\hline & & & $\%$ & $\%$ & $\%$ & $\mathrm{~mm} / \mathrm{m}$ & & \\
\hline & Mwomboshi & 1.5 & 29.6 & 41.3 & 46.7 & 121 & 0.4 & Sandy clay \\
\hline & Lunsemfwa & 1 & 6.6 & 11.3 & 40.3 & 47 & 59.9 & Loamy Sand \\
\hline & Mkushi & 1 & 6.6 & 11.3 & 40.3 & 47 & 59.9 & Loamy Sand \\
\hline & Mulungushi & 1 & 6.6 & 11.3 & 40.3 & 47 & 59.9 & Loamy Sand \\
\hline
\end{tabular}

been facing the problem of failure to fill up. There are two power stations, one at the Mulungushi dam and another at the Mitta hills dam. The Mulungushi dam power plant has the capacity of producing $31 \mathrm{MW}$ and the Mitta hills power plant has the capacity of producing $54 \mathrm{MW}$ [10]. The company produces power and sells to Zambia Electricity Supply Corporation Limited (ZESCO) which then distributes across the country [11]. This study will estimate the volume of water used in irrigation from the year 2013 to 2017 in the basins of the upper reaches of Lunsemfwa, Mulungushi, Mwomboshi, and Mkushi subbasins. This will help in the planning and harmonization of future water use.

\section{Methodology}

2.1. Simulation of Net Irrigation Water by AquaCrop Software. The main model (AquaCrop) used to simulate water abstraction in the basins and its data requirements was used as a guide to collect data. AquaCrop is a menu-driven program with a well-developed user interface. Before running a simulation; the following were specified in the main menu: the sowing date, the simulation period, and the appropriate environmental, initial, and off-season conditions [2]. The ETo calculator was used to calculate ETo. Variables which were used to calculate ETo are minimum and maximum air temperature (Tmin and $\mathrm{Tmax}$, in ${ }^{\circ} \mathrm{C}$ ); air humidity as mean relative humidity ( $\mathrm{RH}$ mean in \%); mean wind speed in meter per seconds measured at two (2) meters above ground; sunshine and net radiation $(\mathrm{Rn})$ in $\mathrm{MJ} / \mathrm{m}^{2}$.day. ETo was calculated in $\mathrm{mm} /$ day from January to December for the period 2013 to 2017. The main equation used by the ETo calculator to calculate ETo is given in (1). Figure 8 shows weather data used to run the ETo calculator from the three weather stations.

$$
\begin{aligned}
& E T_{o} \\
& \qquad=\frac{0.408 \Delta\left(R_{n}-G\right)+\gamma(900 /(T+273)) u_{2}\left(e_{s}-e_{a}\right)}{\Delta+\gamma\left(1+0.34 u_{2}\right)}
\end{aligned}
$$

where

$\mathrm{ET}_{\mathrm{o}}$ denotes reference evapotranspiration $[\mathrm{mm}$ day $\left.^{-1}\right]$,

$\mathrm{R}_{\mathrm{n}}$ denotes net radiation at the crop surface $\left[\mathrm{MJ} \mathrm{m}^{-2}\right.$ day $\left.^{-1}\right]$,

$\mathrm{G}$ denotes soil heat flux density $\left[\mathrm{MJ} \mathrm{m}^{-2} \mathrm{day}^{-1}\right]$,

$\mathrm{T}$ denotes mean daily air temperature at $2 \mathrm{~m}$ height $\left[{ }^{\circ} \mathrm{C}\right]$,

$\mathrm{u}_{2}$ denotes wind speed at $2 \mathrm{~m}$ height $\left[\mathrm{m} \mathrm{s}^{-1}\right]$,

$\mathrm{e}_{\mathrm{s}}$ denotes saturation vapour pressure $[\mathrm{kPa}]$,

$\mathrm{e}_{\mathrm{a}}$ denotes actual vapour pressure $[\mathrm{kPa}]$,

$\mathrm{e}_{\mathrm{s}}-\mathrm{e}_{\mathrm{a}}$ denotes saturation vapour pressure deficit $[\mathrm{kPa}]$,

$\Delta$ denotes slope vapour pressure curve $\left[\mathrm{kPa}^{\circ} \mathrm{C}^{-1}\right]$,

$\gamma$ denotes constant $\left[\mathrm{kPa}^{\circ} \mathrm{C}^{-1}\right]$.

Soil Water Characteristics Hydraulic Properties Calculator was used to estimate soil water characteristics by texture as provided on the soil map of Zambia [9]. ETo, soil, and crop parameters were then fed into AquaCrop model by creating corresponding data file (shown in Table 1) for each subbasin to be used in crop growth simulation.

This gave an estimation of water used by the crop from germination to harvest and was used to calculate gross irrigation water requirements under sprinkler irrigation systems. In this study the climate data was collected from the following weather stations: Lusaka Airport used for Mwomboshi catchment; Mulungushi in Kabwe used for Mulungushi and Lunsemfwa catchment; and Serenje used for Mkushi catchment. All the weather stations have digital data recording system and the information is available online under Southern African Science Service Centre for Climate Change and Adaptive Land Management (SASSCAL) program.

From the meteorological data, ETo was then calculated using ETo calculator version 3.2 of September 2012. 
TABLE 2: Crop parameters used in AquaCrop.

\begin{tabular}{|c|c|c|c|c|}
\hline & \multicolumn{2}{|c|}{ Wheat } & \multicolumn{2}{|c|}{ Soybean } \\
\hline & Length(days) & Date & Length (days) & Date \\
\hline From day 1 after sowing & & 2-May & & 2-May \\
\hline To emergence & 15 & 17-May & 7 & 9-May \\
\hline To maximum Canopy & 50 & 21-May & 40 & 11-Jun \\
\hline To maximum root depth & 65 & 6-Jun & 40 & 11-Jun \\
\hline To start of canopy senescence & 80 & 21-Jul & 70 & 11-Jul \\
\hline To maturity & 120 & 29-Aug & 85 & 25-Jul \\
\hline To flowering & 50 & 21-Jun & 50 & 21-Jul \\
\hline Length building up HI & 8 & End 29 Jun & 32 & end 23 July \\
\hline Duration of flowering & 15 & End 6 Jul & 10 & end 1 July \\
\hline
\end{tabular}

2.2. AquaCrop Crop Data. Crop selection was based on crops grown commercially in the region with wheat as the main irrigated crop in the dry season. Soybean was selected as an alternative crop since it is mainly used in rotation as part of soil fertility management. Additionally, the two crops were representative of major field crops grown in the region and would provide a close estimate of dry season irrigation water abstractions. Table 2 gives a summary of crop data as used in AquaCrop.

2.3. Soil Data Use in AquaCrop. In AquaCrop the soil profile can be composed of up to five different horizons of variable depths, each with their own physical characteristics. The considered hydraulic characteristics are the hydraulic conductivity at saturation $\left(\mathrm{K}_{\mathrm{sat}}\right)$ and soil water content at saturation $\left(\theta_{\text {sat }}\right)$, field capacity $\left(\theta_{\mathrm{FC}}\right)$, and permanent wilting point $\left(\theta_{\mathrm{PWP}}\right)$ [12]. The hydraulic property calculator was used and requires soil texture information in percent by mass of clay and sand (Dr. Keith E. Saxton, 2007). From this information, the type of soil and values for wilting point, field capacity, saturation, saturated hydraulic conductivity, and matric bulk density are estimated [13]. The soil profile is then specified in AquaCrop. For this study the soils were set as described in the soil map of Zambia (Figure 6) which was used at catchment scale to obtain the soil texture information including organic matter content. For this study, crop management was not considered. Monthly rainfall was put in the model for simulation of net irrigation, but mostly the period during simulation was having little or no rainfall (dry season).

2.4. Catchments Delineation. The catchment area for the upper Lunsemfwa basin was defined using shape file from https://earthexplorer.usgs.gov/ under United States Geological Survey (USGS). For this study, the $3 \mathrm{sec}$ DEM ( $30 \mathrm{~m}$ x 30 $\mathrm{m})$ data of USGS HydroSHEDS were collected and used for the derivation of catchment and drainage flow directions.

The map that covers the area under the study was obtained from Short Topography Mission which is downloadable as a Geotiff file [14]. The downloaded footprint Geotiff files were collected from the Quantum Geography Information System (QGIS) software 2.18.19 which is free to download online [15]. The tiles that form the area under the study

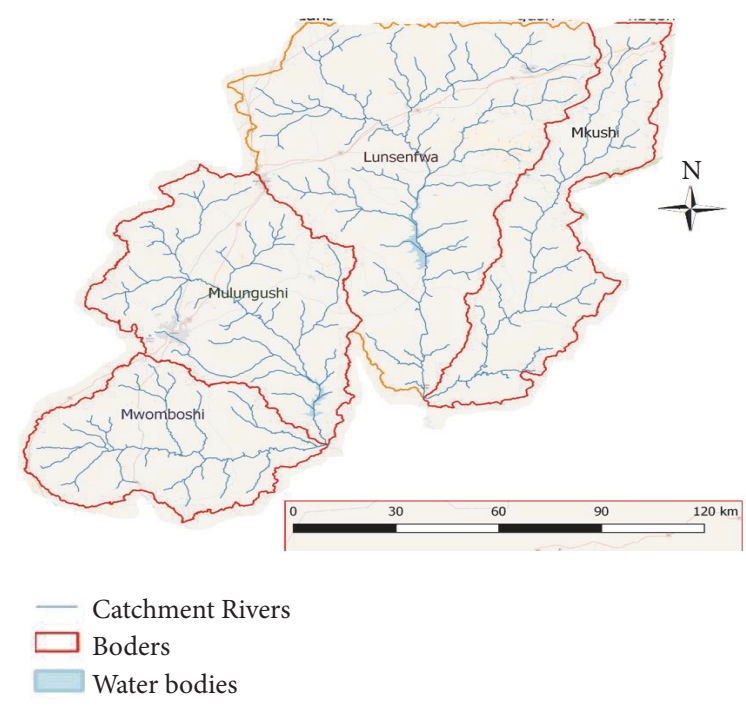

FIGURE 1: Catchment orientation and river networks.

were corrected using the Zambia authority ID of European Petroleum Search Group EPSG (32535) latitude and of World Geographical System (WGS) 72BE/UTM zone 35S coordinate referencing system. This was achieved by using spatial reference online to find the right EPSG code, which covers the study area. The delineated area is represented in Figure 1.

2.5. Irrigation Area Estimation. For this study, the USGS earth explorer website was used to obtain satellite imagery. The procedures for downloading the free images included registering for USGS accounts and searching the desired area of study and then downloading the Geotiff image from Landsat 8 OLI/TIRS archives [14]. Path 171-171 and 172-172 row 70-70 and 69-69, 10 percent clouds cover day for months of May, July, and September 2013 to 2017 was set.

The landsat images were set to the date of early May to August of each year from 2013 to 2017 to cover the period when irrigation is carried out. Landsat imagery (L8OLI/ TIRS) was then clipped to the shape files of the delineated catchments in order to classify irrigated farms. The then clipped catchments were classified as seen from Landsat imagery (L8OLI/TIRS) distinguished by different colours and 
TABLE 3: Proportion of the various sub-basins under irrigation (wheat/soybean) from 2013 to 2017.

\begin{tabular}{lccc}
\hline Catchments & Study Area (ha) & Av. irrigated (ha) & \% irrigated \\
\hline Mkushi & 348000.0 & 2076.7 & 0.6 \\
Lunsemfwa & 779400.5 & 13840.0 & 1.78 \\
Mulungushi & 444500.0 & 2720.0 & 0.61 \\
Mwomboshi & 304300.0 & 2303.3 & 0.76 \\
\hline
\end{tabular}

TABLE 4: Soil physical properties.

\begin{tabular}{|c|c|c|c|c|}
\hline \multirow[t]{2}{*}{ Soil Parameter } & \multicolumn{4}{|c|}{ Catchements } \\
\hline & Mkushi & Lunsemfwa & Mulungushi & Mwomboshi \\
\hline Wilting Point (\%) & 6.6 & 6.6 & 6.6 & 29.6 \\
\hline Field Capacity (\%) & 11.3 & 11.3 & 11.3 & 41.3 \\
\hline Saturation (\%) & 40.3 & 40.3 & 40.3 & 46.7 \\
\hline Organic Matter (\%) & 0.5 & 0.5 & 0.5 & 1.2 \\
\hline Saturated Hydraulic Conductivity $(\mathrm{mm} / \mathrm{hr})$ & 59.9 & 59.9 & 59.9 & 0.4 \\
\hline Soil Type & Loamy sand & Loamy sand & Loamy sand & Sandy Clay \\
\hline
\end{tabular}

spatial geographical features. Areas under irrigation were calculated with the aid of field calculator in the attribute table of every catchment file in QGIS.

For each year, four Landsat imageries (L8OLI/TIRS) for each month of May, July, and August were used, then composited to one image, and clipped to the catchment shape files. This process was repeated for the years 2013 to 2017 in each catchment. Irrigated areas (Figure 7) were results of the average of all irrigation classified area for the months of May, July, and August of each year under the study period. Table 3 shows the average irrigated area classified from the QGIS software and the percentage irrigated with respect to the catchment area over five (5) periods.

The areas were used to calculate the volume of water used after simulation of the net irrigation requirements for each crop in the AquaCrop.

\section{Results}

3.1. Climatic Conditions for Mkushi, Lunsemfwa, Mulungushi, and Mwomboshi Catchments. Reference evapotranspiration ETo was determined using FAO ETo calculator [16] for each catchment. Monthly average ETo for five years was plotted as shown in Figure 2. The results show that ETo is highest at an average of $7.02 \mathrm{~mm}$ /day in Serenje and Mkushi while the least was in Mulungushi at an average of $6.84 \mathrm{~mm} /$ day.

3.2. Soil Types Used for Irrigation Water Estimation. Catchment soil was analyzed using the soil water characteristic software [17] and results are shown in Table 1. Table 4 shows the parameter of loamy sands soil found in the Lunsemfwa, Mulungushi, and Mkushi catchment area.

3.3. AquaCrop Simulation and Net Irrigation Estimation. The results from the catchments and soil characteristics were used to set the AquaCrop model simulation of net irrigating requirements [1] for wheat and soybean. Wheat gave higher net irrigation water equipment than soybean. This helps in

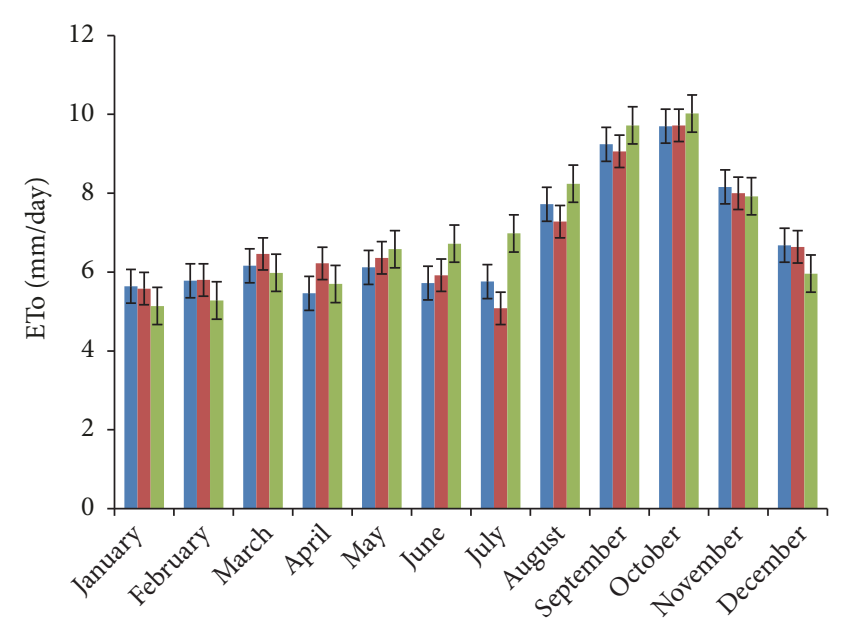

MONTHS

$$
\begin{aligned}
& \text { - Mwomboshi } \\
& \text { - Kabwe Mulungushi } \\
& \text { - Serenje Mkushi }
\end{aligned}
$$

Figure 2: Five-year average monthly ETo Mkushi, Mwomboshi, Lunsemfwa, and Mulungushi catchment.

estimating the minimum and maximum water that could be abstracted due to irrigation. Net irrigation water requirement is represented in Figure 3. ETo of the crop varies as simulated by the ETo calculator giving alternating values of net irrigation from 2013 to 2017. Mulungushi and Lunsemfwa show similar values as a result of same weather and soil type [18]. From Figure 3 cumulative ETo for wheat and soybean are different because of differences in length of growing season. Wheat recorded higher values for cumulative ETo as it was simulated for longer period (120 days) while soybean was simulated for shorter periods ( 85 days). ETo influenced the net irrigation water, due to alternating solar radiation, 

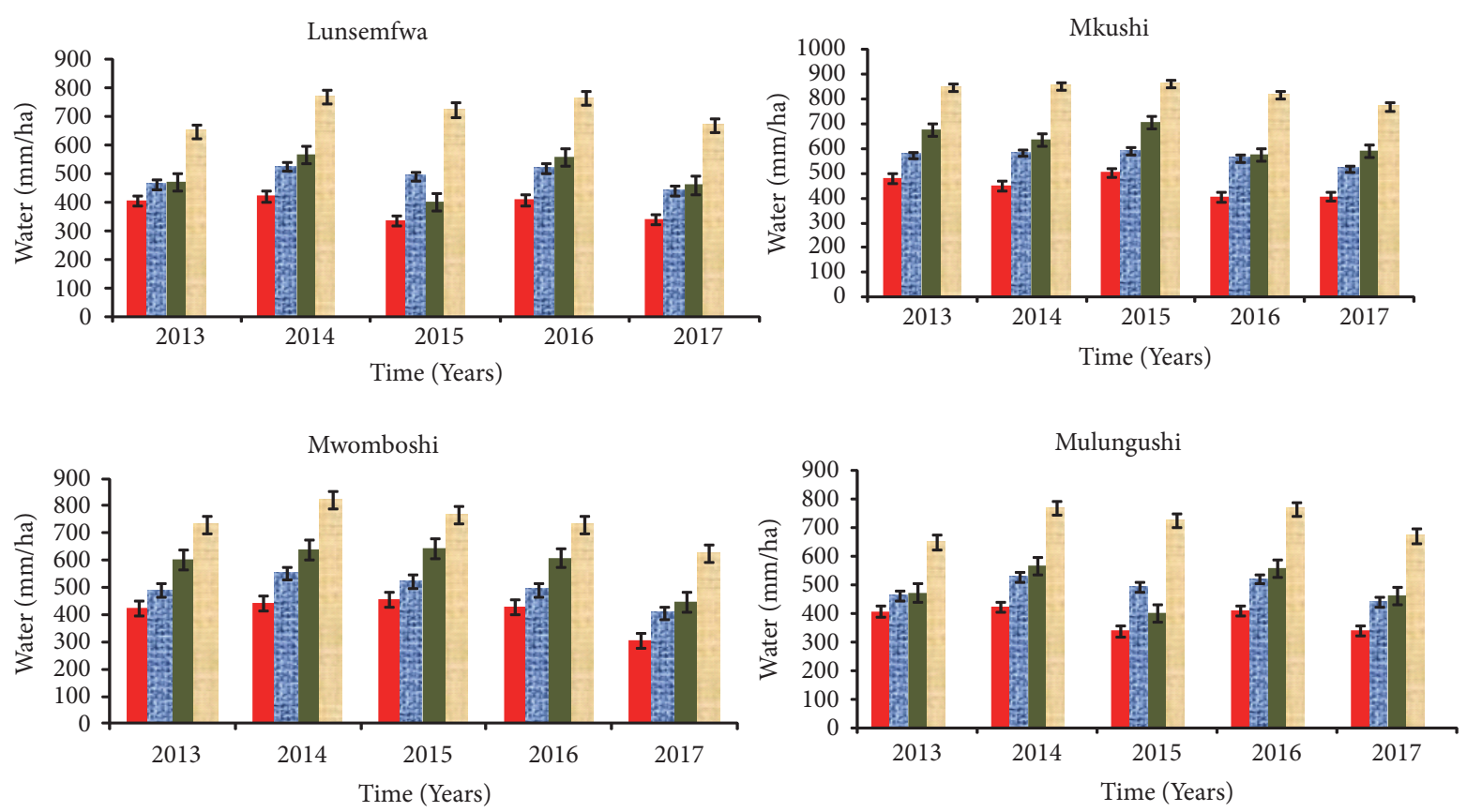

\section{Soybean Net Irrigation Soybean cumulative ETo \\ Wheat Net Irrigation Wheat cumulative ETo}

FIGURE 3: Yearly analysis of net irrigation per hectare and evapotranspiration from soybean and wheat in Mkushi, Lunsemfwa, Mulungushi, and Mwomboshi catchments.

TABLE 5: Parameter of study area.

\begin{tabular}{lcccc}
\hline Parameter & & \multicolumn{3}{c}{ Catchments } \\
& Mkushi & Lunsemfwa & Mulungushi & Mwomboshi \\
\hline Catchment area $\left(\mathrm{km}^{2}\right)$ & 3480.0 & 7794.48 & 4445.0 & 3043.0 \\
Irrigated area $\left(\mathrm{km}^{2}\right)$ & 20.8 & 138.4 & 27.2 & 23.0 \\
Average Yearly Rainfall $(\mathrm{mm})$ & 1032.68 & 1165.54 & 1165.54 & 882.64 \\
Max Volume abstracted $\left(\mathrm{m}^{3}\right)$ & 66413317 & $3.40 \mathrm{E}+08$ & $6.60 \mathrm{E}+07$ & $6.81 \mathrm{E}+07$ \\
Min Volume abstracted $\left(\mathrm{m}^{3}\right)$ & 46737683 & $4.67 \mathrm{E}+07$ & $5.48 \mathrm{E}+07$ & $4.10 \mathrm{E}+07$ \\
Soil Type & Loamy sand & Loamy sand & Loamy sand & Sandy Clay Loam \\
\hline
\end{tabular}

humidity, and wind speeds recorded from weather station resulting in alternating ETo. It was also due to variability in air temperature affecting both ETo and the length of crop growing season (Allen 2008).

3.4. Volumes of Water Abstraction. The volume of water was estimated from irrigated areas (Figure 7) and gross irrigation water requirements for wheat and soybean. The assumption was that the crops were irrigated by sprinkler with an efficiency of 0.75 . Figure 4 shows that all irrigation water abstracted from the study area would increase depending on the crop irrigated. It was estimated that the average abstraction in all catchments was $107,727,813 \mathrm{~m}^{3}$. The maximum volume was $119,680,200 \mathrm{~m}^{3}$ overall in 2013 , while the minimum was estimated to be in 2014 at $74,951,400 \mathrm{~m}^{3}$. In simple terms the maximum irrigation water abstraction decreased from $2013\left(119,680,200 \mathrm{~m}^{3}\right)$ to $2015(94,686,566.66$ $\mathrm{m}^{3}$ ), increased to $118,193,500 \mathrm{~m}^{3}$ in 2016 , and reduced in 2017 to $100,715,566 \mathrm{~m}^{3}$. The minimum irrigated water abstraction drop from $98,272,900 \mathrm{~m}^{3}$ in 2013 to $77,944,500 \mathrm{~m}^{3}$ in 2014, then increased to $93,979,933.33 \mathrm{~m}^{3}$ in 2015 , and lastly dropped in 2016 and 2017 to 74,951,400 $\mathrm{m}^{3}$. The summary is included in Table 5 and Figure 5.

\section{Discussion}

4.1. Catchment Evapotranspiration. The findings for the period of study suggests that Serenje weather station, as used for weather to calculate ETo for Mkushi catchment [11], has highest ETo while the lowest was in Mwomboshi catchment. This is in agreement with geographical locations of the catchment as Serenje (located in the northern end of Mkushi catchment) is further north and closer to the equator while Kabwe (used for Mwomboshi catchment) is in the southern end and slightly far from the equator. Figure 3 reviews a 


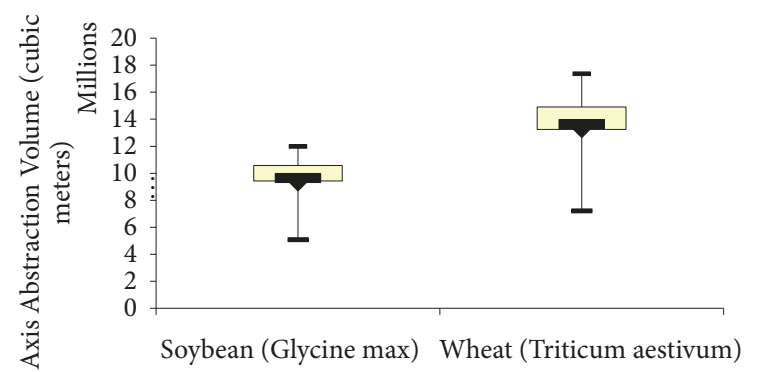

Mkushi

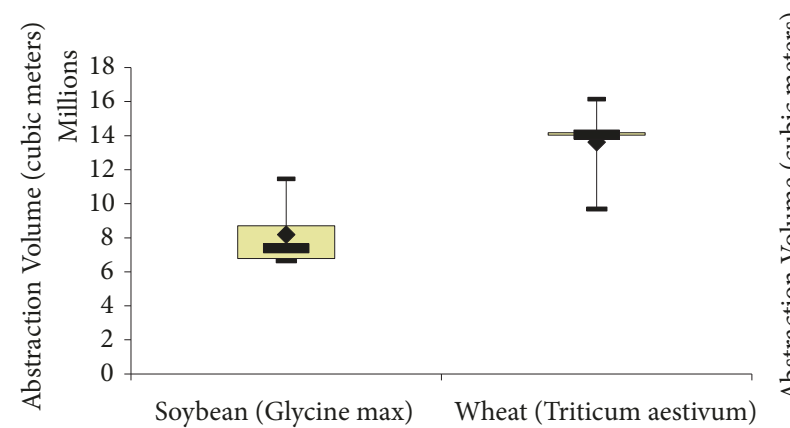

Mwomboshi
- Minimum
- Mean
- Median
- Maximum

FIGURE 4: Average wheat and soybean water abstraction from Lunsemfwa.
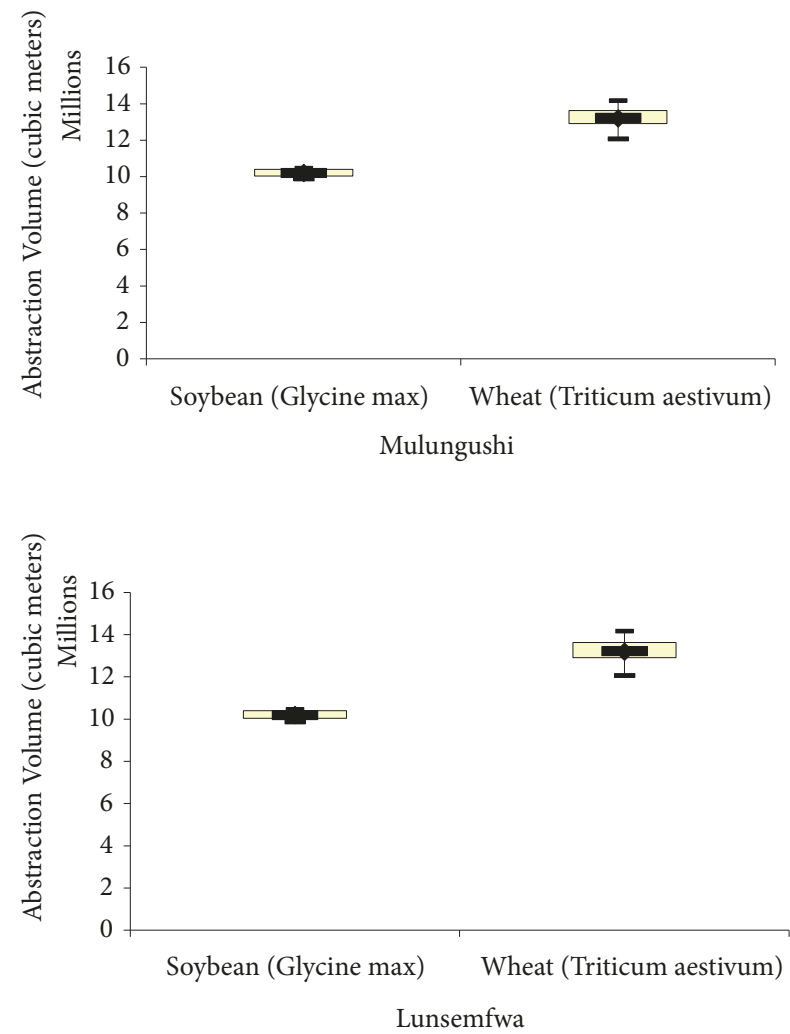
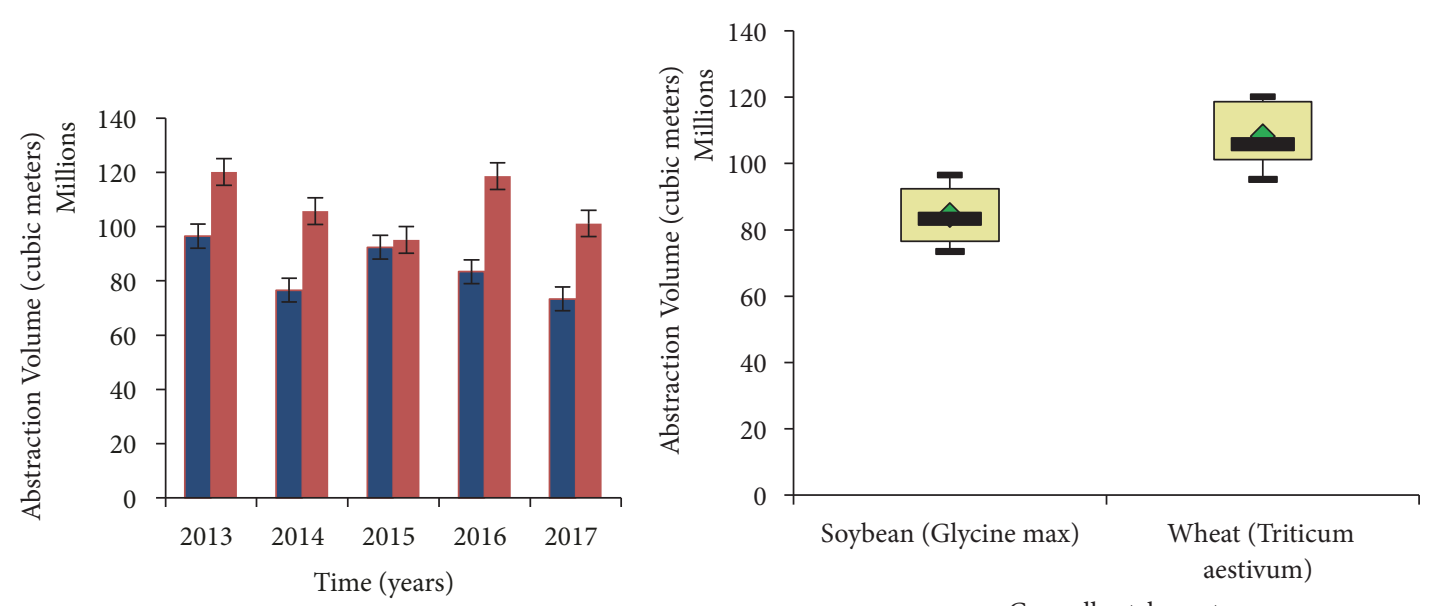

Soybean (Glycine max)

- Wheat (Triticum aestivum)

1st quaetile

Crop all catchments

- Minimum

- Mean

- Median

- Maximum 3rd Quartile

(a)

(b)

Figure 5: (a) Total annual abstraction volumes and (b) average annual for each crop. 
TABLE 6: Multiple Comparisons of wheat Net irrigation water [mm/ha] 2013 to 2017 LSD.

\begin{tabular}{|c|c|c|c|c|c|c|}
\hline \multirow[t]{2}{*}{ (I) Catchment } & \multirow[t]{2}{*}{ (J) Catchment } & \multirow[t]{2}{*}{ Mean Difference (I-J) } & \multirow[t]{2}{*}{ Std. Error } & \multirow[t]{2}{*}{ Sig. } & \multicolumn{2}{|c|}{ 95\% Confidence Interval } \\
\hline & & & & & Lower Bound & Upper Bound \\
\hline \multirow{2}{*}{ Lunsemfwa } & Mkushi & -146.66 & 44.045 & 0.01 & -242.625 & -50.694 \\
\hline & Mwomboshi & -96.42 & 44.045 & 0.05 & -192.385 & -0.454 \\
\hline \multirow{2}{*}{ Mkushi } & Lunsemfwa & 146.66 & 44.044 & 0.01 & 50.694 & 242.625 \\
\hline & Mwomboshi & 50.24 & 44.044 & 0.28 & -45.725 & 146.205 \\
\hline \multirow{2}{*}{ Mwomboshi } & Lunsemfwa & 96.42 & 44.044 & 0.05 & 0.454 & 192.385 \\
\hline & Mkushi & -50.24 & 44.044 & 0.28 & -146.205 & 45.725 \\
\hline
\end{tabular}

"Based on observed means: The error term is Mean Square (Error) $=4849.887$."

*. The mean difference is significant at the 0.05 level.

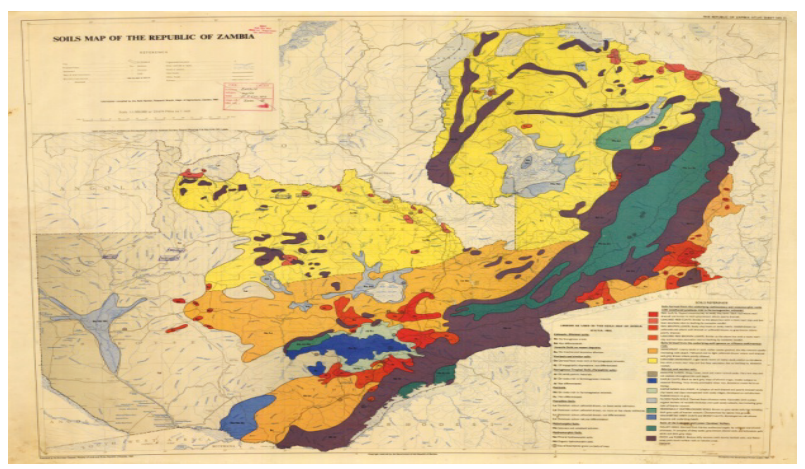

FIgURE 6: Soil map of Zambia which was used to obtain the soil characteristics of the four catchments under study https://www .google.co.zm/search?q=soil+map+of+zambia\&rlz=1C1CHBF.

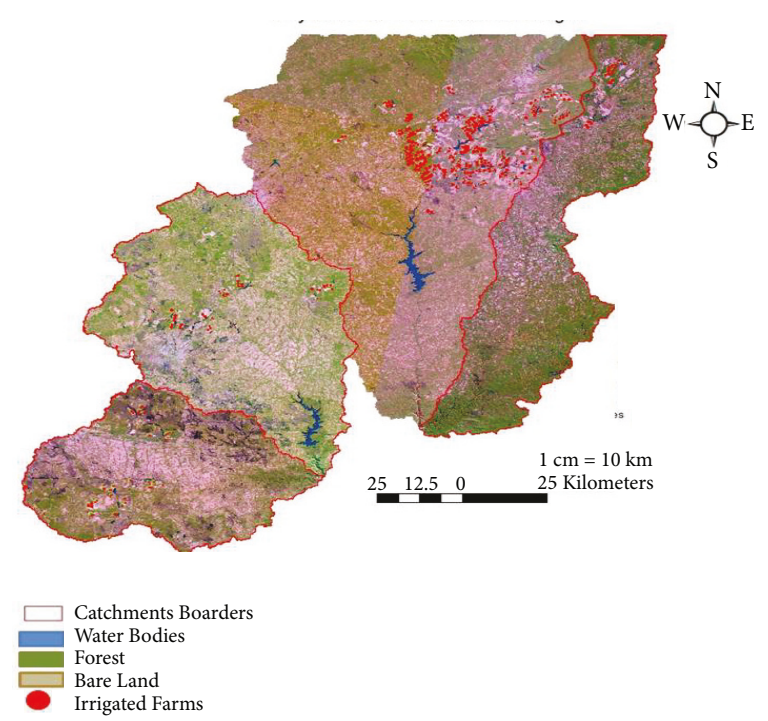

Figure 7: Classified landsat images from study area showing classified irrigated area.

close relationship between seasonal net irrigation and ETo for both wheat and soybean. Thus net irrigation is influenced by cumulative ETo during the growing season [19] as evidenced by relatively high water demands per hectare in Mkushi catchment. For the same crops and soil type simulation in Mkushi, Lunsemfwa, and Mulungushi, the differences in weather influenced seasonal ETo and consequently net irrigation requirements (Karam et al., 2007). Despite using catchment averaged soil and weather characteristics, the resulting irrigation water requirements are in an acceptable range of $410 \mathrm{~mm}-510 \mathrm{~mm}$ for soybeans and $450 \mathrm{~mm}-710 \mathrm{~mm}$ for wheat. The FAO guideline gives a range from $450 \mathrm{~mm}$ to $700 \mathrm{~mm}$ and $450 \mathrm{~mm}$ to $650 \mathrm{~mm}$ for soybeans and wheat, respectively.

4.2. Irrigation Areas and Volumes in the Basins. According to the findings, Lunsemfwa catchment is the largest irrigated area as affirmed by [20] with Mkushi catchment showing low irrigated areas as demonstrated in Figure 7. Although other catchments have availability of water somehow the Lunsemfwa area has more access to roads and electricity as well as good soil for growing crops leading to high irrigated area. Table 6 shows the variation in mean irrigated area for all catchments. Although the classification process was good in identifying most irrigated areas under pivot irrigation systems, poor resolution of free online satellite images has limited accuracy.

Further study or research should be carried out using remote sensed images with higher resolutions.

Volume of irrigation abstraction is greatly influenced by area under irrigation. It can be seen from Table 5 that Lunsemfwa basin has the highest volume while Mkushi has the lowest and this same trend is observed for irrigation areas, respectively. Although amount of areas irrigated has impact on the amount of volume abstracted it was not the case with Mwomboshi which has second highest abstraction and third highest irrigated area (Table 5). This was due to the different soil type (Sandy clay) from the other three catchments as well as the thickness of the soil horizon (Table 1).

\section{Conclusions and Recommendations}

The volumes of irrigation water abstracted from the catchments were estimated to be highest in the Lunsemfwa catchment at average of $6.78 \times 10^{7} \mathrm{~m}^{3}$ in the fiveyear period followed by an averages of $1.36 \times 10^{7} \mathrm{~m}^{3}$ in Mwomboshi catchment and Mkushi at $1.32 \times 10^{7} \mathrm{~m}^{3}$ and 


\begin{tabular}{|c|c|c|c|c|c|c|c|c|c|c|c|c|c|c|c|c|c|c|c|c|}
\hline \multicolumn{21}{|c|}{ kabwe Mulungushi weathe data } \\
\hline rainfall & 2013 & 2014 & 2015 & 2016 & 2017 & average & min tem & 2013 & 2014 & 2015 & 2016 & 2017 & average & max tem & 2013 & 2014 & 2015 & 2016 & 2017 & iverage \\
\hline Jan-13 & & 300.1 & 2924 & 365.6 & 427.8 & 3465 & Jan-13 & & 16.4 & 15.1 & 15.3 & $17^{\prime}$ & 16.0 & Jan-13 & & 31.1 & 30.7 & 35.1 & 29.4 & 31.6 \\
\hline Feb-13 & & 169.2 & 1380 & 177.4 & 3468 & 207.9 & Feb-13 & & 16 & 15.6 & 17.3 & $17.3^{\prime}$ & 16.6 & Feb-13 & & 29.7 & 31 & 33.4 & 30.6 & 31.2 \\
\hline Mar-13 & & 223.8 & 90.0 & 275.6 & 3140 & 225.9 & Mar-13 & & 13.7 & 12.4 & 16.1 & 11.7 & 13.5 & Mar-13 & & 30.6 & 32.7 & 32.1 & 45.5 & 35.2 \\
\hline Apr-13 & & 20.4 & 113.6 & 39.8 & 29.0 & 50.7 & Apr-13 & & 11.1 & 8.7 & 9.2 & 12 & 10.3 & Apr-13 & & 31.3 & 28.6 & 30.3 & 48 & 34.6 \\
\hline May-13 & & 0.0 & 0.0 & 0.0 & 0.0 & 0.0 & May-13 & & 5.4 & 5.5 & 4.5 & $11.4^{\prime}$ & 6.7 & May- 13 & & 30 & 29.1 & 29.6 & 29.9 & 29.7 \\
\hline Jun-13 & & 0.0 & 0.0 & 0.0 & 0.0 & 0.0 & Jun-13 & & 2.6 & 2.4 & 2.8 & 4 & 3.0 & Jun-13 & & 30.6 & 29.6 & 27.4 & 27.4 & 28.8 \\
\hline Jul-13 & & 0.0 & 0.0 & 0.0 & 0.0 & 0.0 & Jul-13 & & 2.3 & 13 & 2.3 & 3 & 5.2 & Jul-13 & & 28.8 & 32.1 & 31 & 27.8 & 29.9 \\
\hline Sep-13 & & 0.2 & 0.0 & 0.4 & 0.0 & 0.2 & Sep-13 & & 4.8 & 12 & 8.5 & 4.8 & 7.5 & Sep-13 & & 35.7 & 34.7 & 35.4 & 35.3 & 35.3 \\
\hline Oct-13 & 46.2 & 5.2 & 0.0 & 0.0 & 31.0 & 16.5 & Oct-13 & 13.8 & 10.8 & 11.8 & 11.8 & $10.2^{\prime \prime}$ & 11.7 & Oct-13 & 36.8 & 36.9 & 37.4 & 37.2 & 38.4 & 37.3 \\
\hline Nov-13 & 55.9 & 10.4 & 81.0 & 243.0 & 180.0 & 114.1 & Nov-13 & 16.3 & 12.8 & 11.5 & 15.5 & $14.2^{\prime}$ & 14.1 & Nov-13 & 36.4 & 36.8 & 37 & 36.4 & 35.8 & 36.5 \\
\hline Dec-13 & 73.4 & 347.6 & 217.2 & 241.8 & 2766 & 231.3 & Dec-13 & 16.5 & 15.9 & 16.4 & 16.9 & $14.2^{\prime \prime}$ & 16.0 & Dec-13 & 35.0 & 35 & 35.4 & 32.9 & 31.4 & 33.9 \\
\hline humidiy \% & 2013 & 2014 & 2015 & 2016 & 2017 & average & wind $\mathrm{mm} / \mathrm{s}$ & 2013 & 2014 & 2015 & 2016 & 2017 & average & rn solar & 2013 & 2014 & 2015 & 2016 & 2017 & verage \\
\hline Jan-13 & & 83.8 & 85.8 & 78.8 & 88.7 & 84.3 & Jan-13 & & 0.5 & 0.3 & 0.8 & 0.8 & 0.6 & Jan- 13 & & 19.1917 & 18.2462 & 18.82541 & 15.99585 & 18.1 \\
\hline Feb-13 & & 87.4 & 84.3 & 82.6 & $88.9^{\circ}$ & 85.8 & Feb-13 & & 0.4 & 0.3 & 0.6 & 0.4 & 0.4 & Feb-13 & & 16.94507 & 20.86311 & 20.98886 & $16.940 \pi$ & 18.9 \\
\hline Mar-13 & & 83.4 & 80.3 & 87.0 & $87.8^{\circ}$ & 84.6 & Mar-13 & & 1.5 & 1.9 & 0.9 & $1.4^{\prime \prime}$ & 1.4 & Mar- 13 & & 20.8754 & 22.03424 & 18.63587 & 17.39847 & 19.7 \\
\hline May-13 & & 70.6 & 74.7 & 71.0 & 64.7 & 70.3 & May-13 & & 2.0 & 1.8 & 2.2 & & 2.0 & May-13 & & 19.85948 & 21.16008 & 20.19616 & 17.94845 & 19.8 \\
\hline Jun-13 & & 66.6 & 71.0 & 68.6 & 71.7 & 69.5 & Jun-13 & & 2.0 & 1.7 & 2.0 & & 1.9 & Jun-13 & & 18.02697 & 14.7073 & 19.54648 & 16.76539 & 17.3 \\
\hline Jul-13 & & 63.9 & 47.1 & 65.4 & 66.0 & 60.6 & Jul-13 & & 1.8 & 0.1 & 1.9 & & 1.3 & Jul-13 & & 19.25007 & 1.089 & 17.4376 & 10.49552 & 12.1 \\
\hline Aug-13 & & 54.1 & 46.8 & 55.2 & 60.9 & 54.2 & Aug-13 & & 2.1 & 0.2 & 2.6 & & 1.6 & Aug-13 & & 19.92906 & $1.6375 \mathrm{Z}$ & 20.13721 & 20.81012 & 15.6 \\
\hline Sep-13 & & 45.3 & 38.1 & 40.5 & 46.8 & 42.7 & Sep-13 & & 2.4 & 2.1 & 2.5 & & 2.3 & Sep-13 & & 22.69639 & 6.777564 & 22.31879 & 22.62672 & 18.6 \\
\hline Oct-13 & 46.8 & 42.3 & 38.4 & 36.8 & 50.4 & 42.9 & Oct-13 & 1.8 & 2.1 & 2.5 & 2.5 & & 2.2 & Oct-13 & 18.66 & 24.93129 & 24.16651 & 23.83979 & 20.53104 & 22.4 \\
\hline Nov-13 & 56.3 & 49.4 & 55.7 & 61.3 & $72.0^{\circ}$ & 58.9 & Nov-13 & 1.5 & 1.7 & 1.1 & 1.6 & & 1.5 & Nov-13 & 24.89 & 23.55325 & 21.72694 & 20.65534 & 20.32272 & 22.2 \\
\hline Dec-13 & 75.4 & 73.9 & 75.5 & 81.7 & 85.4 & 78.4 & Dec-13 & 0.9 & 0.4 & 0.6 & 0.7 & & 0.7 & Dec-13 & 20.52 & 18.40336 & 21.749 & $19.767 \oplus$ & 18.7374 & 19.8 \\
\hline
\end{tabular}

\begin{tabular}{|c|c|c|c|c|c|c|c|c|c|c|c|c|c|c|c|c|c|c|c|c|}
\hline \multicolumn{21}{|c|}{ Serenje weather station } \\
\hline rainfall & 2013 & & & & & & min tem & 2013 & & & & & & max tem & 2013 & & & & & \\
\hline Jan-13 & & 1465 & 399.4 & 178.4 & 12.2 & 184.1 & 412750 & & 14.9 & 14.8 & 15.2 & 16.0 & 15.2 & 412750 & & 28.6 & 28.7 & 30.5 & 29.6 & 29.4 \\
\hline Feb-13 & & 273.7 & 265.0 & 2124 & 159.8 & 227.7 & 413060 & & 15.5 & 14.7 & 15.8 & 15.2 & 15.3 & 413060 & & 28.5 & 30.4 & 31.1 & 30.2 & 30.1 \\
\hline Mar-13 & & 787.6 & 117.4 & 307.0 & 4.6 & 304.2 & 413340 & & 15.0 & 12.8 & 13.4 & $13.3^{\circ}$ & 13.6 & 413340 & & 29.5 & 30.4 & 30.7 & 28.1 & 29.7 \\
\hline Apr-13 & & 40.2 & 90.8 & 11.4 & 47.8 & 47.6 & 413650 & & 10.2 & 9.8 & 10.8 & $13.3^{\prime \prime}$ & 11.0 & 413650 & & 29.3 & 28.6 & 29.3 & 29.4 & 29.2 \\
\hline May-13 & & 0.0 & 0.4 & 0.0 & 0.0 & 0.1 & 413950 & & 7.0 & 6.8 & 6.4 & $9.9^{\circ}$ & 7.5 & 413950 & & 27.6 & 27.2 & 28.2 & 27.5 & 27.6 \\
\hline Jul-13 & & 0.0 & 0.0 & 0.0 & 6.0 & 1.5 & 414560 & & 4.8 & 5.5 & 5.4 & $5.2^{\circ}$ & 5.2 & 414560 & & 28.5 & 28.8 & 28.5 & 25.8 & 27.9 \\
\hline Aug-13 & & 0.0 & 0.0 & 0.0 & 3.2 & 0.8 & 41487.0 & & 7.9 & 6.1 & 7.4 & 9.4 & 7.7 & 41487.0 & & 31.7 & 29.5 & 29.5 & 30.1 & 30.2 \\
\hline Sep-13 & & 0.0 & 12.8 & 0.0 & 0.0 & 3.2 & 415180 & & 10.8 & 9.8 & 10.1 & 11.5 & 10.6 & 415180 & & 33.3 & 32.8 & 32.9 & 33.5 & 33.1 \\
\hline Oct-13 & 0.2 & 0.0 & 15.0 & 9.8 & 8.2 & 6.6 & 415480 & 13.8 & 13.4 & 14.6 & 13.4 & $12.5^{\circ}$ & 13.5 & 415480 & 35.1 & 35.2 & 34.9 & 34.3 & 36.3 & 35.2 \\
\hline Nov-13 & 51.4 & 0.6 & 61.2 & 16.6 & 67.6 & 39.5 & 415790 & 16.3 & 14.8 & 12.8 & 14.3 & $14.6^{\prime \prime}$ & 14.6 & 415790 & 36.4 & 34.9 & 35.9 & 34.8 & $33.5^{\circ}$ & 35.1 \\
\hline Dec-13 & 265.4 & 34.8 & 261.2 & 26.4 & 24.0 & 1224 & 416090 & 16.5 & $\begin{array}{l}14.7 \\
14.7\end{array}$ & 16.1 & $\begin{array}{l}14.7 \\
14.9\end{array}$ & $13.5^{\circ}$ & 15.1 & 416090 & 32.2 & 31.8 & 33.4 & 30.9 & 31.3 & 31.9 \\
\hline humidity $\%$ & $\frac{2034}{2013}$ & & 201.2 & 20.4 & $\frac{240}{0.70}$ & 1224 & wind $\mathrm{m} / \mathrm{s}$ & $\frac{10.3}{0130}$ & 20140 & & & & 10.1 & rn solar & $\frac{1.2}{0130}$ & 20140 & 0.4 & 10160 & 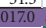 & 1.9 \\
\hline Feb-13 & & $\begin{array}{l}80.4 \\
89.4\end{array}$ & $\begin{array}{l}86.4 \\
86.4\end{array}$ & 85.6 & 89.5 & 87.7 & 413060 & & 0.2 & 0.4 & 0.8 & 0.4 & 0.5 & 413060 & & 15.0 & $\begin{array}{l}18.2 \\
18.2\end{array}$ & $\begin{array}{l}10.4 \\
20.1\end{array}$ & 16.3 & 17.4 \\
\hline Mar-13 & & 83.2 & 79.2 & 86.4 & 87.8 & 84.2 & 413340 & & 2.3 & 2.7 & 1.5 & $2.3^{\circ}$ & 2.2 & 413340 & & 19.7 & 21.9 & 19.0 & 17.8 & 19.6 \\
\hline Apr-13 & & 79.8 & 82.9 & 76.4 & 85.0 & 81.0 & 413650 & & 3.3 & 2.9 & 3.6 & $3.6^{\prime \prime}$ & 3.4 & 413650 & & 17.9 & 17.1 & 19.2 & $17.8^{\circ}$ & 18.0 \\
\hline May-13 & & 66.6 & 67.7 & 67.3 & 78.2 & 70.0 & 413950 & & 3.6 & 3.4 & 3.6 & $3.6^{\circ}$ & 3.5 & 413950 & & 20.7 & 21.6 & 20.7 & $18.7^{\circ}$ & 20.4 \\
\hline Jun-13 & & 59.3 & 62.7 & 63.1 & 69.1 & 63.6 & 414260 & & 3.6 & 3.4 & 3.5 & $3.7^{\circ}$ & 3.5 & 414260 & & 19.3 & 20.3 & 20.2 & 19.5 & 19.8 \\
\hline Jul-13 & & 57.4 & 56.5 & 58.7 & 62.4 & 58.7 & 414560 & & 3.3 & 3.2 & 3.3 & $3.6^{\prime \prime}$ & 3.3 & 414560 & & 19.6 & 20.9 & 18.3 & $20.1^{-}$ & 19.7 \\
\hline Aug-13 & & 48.3 & 48.2 & 51.6 & 55.1 & 50.8 & 414870 & & 3.6 & 3.7 & 4.0 & $3.7^{\circ}$ & 3.7 & 41487.0 & & 20.1 & 21.9 & 20.1 & 20.8 & 20.7 \\
\hline Sep-13 & & 42.9 & 43.0 & 39.4 & 42.4 & 41.9 & 415180 & & 3.9 & 3.6 & 3.4 & $3.9^{\prime \prime}$ & 3.7 & 415180 & & 23.5 & 22.0 & 23.3 & 23.4 & 23.0 \\
\hline Oct-13 & 44.2 & 42.0 & 40.4 & 37.0 & 47.3 & 42.2 & 415480 & 3.0 & 3.1 & 3.4 & 3.3 & $2.9^{\circ}$ & 3.2 & 415480 & 14.7 & 24.5 & 23.8 & 24.4 & $21.6^{\circ}$ & 21.8 \\
\hline Nov-13 & 54.3 & 48.9 & 59.9 & 59.7 & 73.1 & 59.2 & 415790 & 2.7 & 2.6 & 1.8 & 2.3 & $2.0^{\prime \prime}$ & 2.3 & 415790 & 14.3 & 24.0 & 22.1 & 20.6 & $18.8^{\circ}$ & 20.0 \\
\hline Dec-13 & 77.5 & 72.9 & 78.9 & 85.4 & 85.0 & 80.0 & 416090 & 1.1 & 0.4 & 0.6 & 1.0 & $1.2^{\prime \prime}$ & 0.8 & 416090 & 15.3 & 18.0 & 20.8 & 18.3 & 20.2 & 18.5 \\
\hline
\end{tabular}

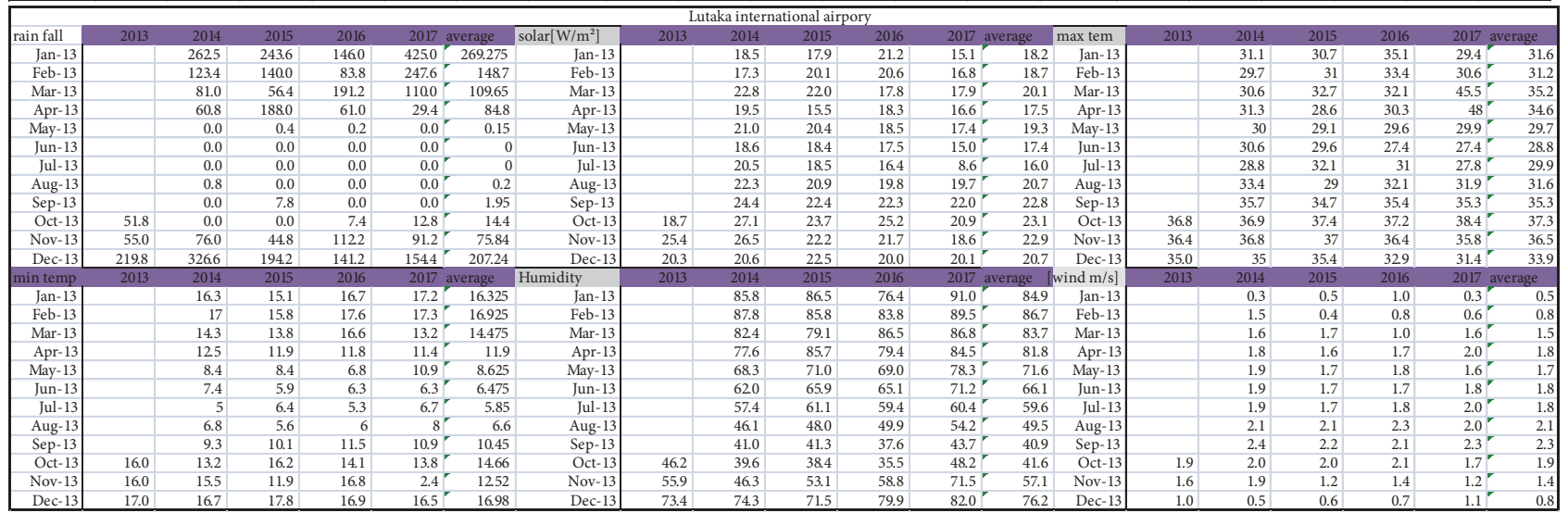

FIGURE 8: Weather data from Serenje, Kabwe, and Lusaka airport Zambia.

lowest average in Mulungushi at $1.31 \times 10^{7} \mathrm{~m}^{3}$. The large abstraction is due to bigger irrigation area in the Lunsemfwa catchment. The following are the recommendations:

(1) Doing bathymetric studies on the dams upstream to ascertain the amount of water farmers are capable of storing. This is to make abstraction studies more accurate and to improve information availability for future planning.

(2) To compliment remote sensing applications, field surveys and experiments need to be carried out to validate the software results. 


\section{Appendix}

\section{A. Input Weather Data Used to Calcuate ETo in ETo Calculator}

See Figures 2, 3, 4, 5, 6, and 7 and Tables 4 and 5 .

Weather Data. See Figure 8.

\section{B. SPSS Least Significant Different Comparisons Results}

Based on observed means, the error term is mean square (error) $=47340650502465.200 . "$

*The mean difference is significant at the 0.05 level.

See Table 6.

\section{Data Availability}

The data used to support the findings of this study are included as the supplementary information file.

\section{Conflicts of Interest}

The authors declare that there are no conflicts of interest regarding the publication of this paper.

\section{Acknowledgments}

I am highly obliged to my sponsors, Mobility to Enhance Training of Engineering Graduates in Africa (METEGA), first for awarding me the scholarship to pursue a MEngAgricultural Engineering at the University of Zambia and secondly covering the tuition fees and the other necessary support such as medical insurance and a monthly stipend. Without these, this paper would not have been possible. Honest appreciation goes to my supervisors Mr. K. Mulonda and Dr. Isaac N. Simate for their insightful contribution that helped me stay on track and finish this paper within the time frame allocated to the study.

\section{Supplementary Materials}

Excel file used to support the findings of this study. (Supplementary Materials)

\section{References}

[1] R. Stricevic, M. Cosic, N. Djurovic, B. Pejic, and L. Maksimovic, "Assessment of the FAO AquaCrop model in the simulation of rainfed and supplementally irrigated maize, sugar beet and sunflower," Agricultural Water Management, vol. 98, no. 10, pp. 1615-1621, 2011.

[2] C. F. Yamba, H. Walimwipi, H. Kling et al., "Water supply and demand scenarios for the Zambezi river," Basin Climate Change and Upstream Development Impacts on New Hydropower Projects in the Zambezi Project Report for Climate \& Development Knowledge Network Lead Author: Randall SpaldingFecher, 2014.

[3] J. K. Kiprop, J. K. Lagat, P. Mshenga, and A. M. Macharia, "Determining the economic value of irrigation water in Kerio
Valley Basin (Kenya) by residual value method," Journal of Economics and Sustainable Development, vol. 6, no. 7, pp. 102108, 2015.

[4] T. Uhlendahl, P. Salian, C. Casarotto, and J. Doetsch, "Good water governance and IWRM in Zambia: Challenges and chances," Water Policy, vol. 13, no. 6, pp. 845-862, 2011.

[5] F. N. Gichuki, "Hydrological impacts of flood storage and management on irrigation water abstraction in upper Ewaso Ng'iro River Basin, Kenya," Water Resources Management, pp. 1859-1879, 2008.

[6] J. Osorio, J. Jeong, K. Bieger, and J. Arnold, "Influence of Potential Evapotranspiration on the Water Balance of Sugarcane Fields in Maui, Hawaii," Journal of Water Resource and Protection, pp. 852-868, 2014.

[7] R. G. Allan, L. S. Pereira, D. Raes, and M. Smith, "Crop evapotranspiration-Guidelines for computing crop water requirements-FAO Irrigation and drainage paper 56," 1998.

[8] R. G. Allen, L. S. Pereira, D. Raes, M. Smith, and W. Ab, "Crop evapotranspiration - Guidelines for computing crop water requirements," FAO Irrigation and Drainage Paper 56, 1998.

[9] K. T. Zeleke and L. J. Wade, "Evapotranspiration estimation using soil water balance, weather and crop data," in Evapotranspiration - Remote Sensing and Modeling, 2009.

[10] B. Lawson, "Mulungushi hydropower project - Environmental and Social Impact Assessment (ESIA)," Mulungushi Hydropower Project Draft Scoping Report, Environmental Resources Management, 2013.

[11] M. Everett, "Muchinga Hydropower Project - Environmental and Social Impact Assessment (ESHIA) Muchinga Hydropower Project Draft Scoping," Report Version 2, 2013.

[12] D. Raes, P. Steduto, T. C. Hsiao, and E. Fereres, "Calculation procedures AquaCrop," 2012.

[13] D. Raes, P. Steduto, T. C. Hsiao, and E. Fereres, "Users guide AquaCrop," 2012.

[14] F. Akram, M. G. Rasul, M. M. K. Khan, and M. S. I. I. Amir, "Automatic Delineation of Drainage Networks and Catchments using DEM data and GIS Capabilities: a case study," 2012.

[15] T. Athan, P. Ersts, and O. D. Werner Macho, "QGIS User Guide," 2018. https://docs.qgis.org/2.18/pdf/en/QGIS-2.18-UserGuideen.pdf.

[16] D. Raes, “The ETo Calculator Table of Contents," 2012.

[17] K. E. Saxton and W. J. Rawls, "Soil water characteristic estimates by texture and organic matter for hydrologic solutions," Science Society of America Journal, vol. 70, no. 5, pp. 1569-1578, 2006.

[18] A. Chapman, H. Walimwipi, and H. Kling, "The vulnerability of hydropower production in the Zambezi River Basin to the impacts of climate change and irrigation," Mitigation and Adaptation Strategies for Global Change, vol. 21, no. 5, pp. 721742, 2016.

[19] S. Er-Raki, A. Chehbouni, N. Guemouria, B. Duchemin, J. Ezzahar, and R. Hadria, "Combining FAO-56 model and groundbased remote sensing to estimate water consumptions of wheat crops in a semi-arid region," Agricultural Water Management, vol. 87, no. 1, pp. 41-54, 2007.

[20] I. Malasha, "Food security and poverty alleviation through improved valuation and Governance of river fisheries in africa the governance of small scale fisheries in Zambia," Submitted to the Research Project on Food Security and Poverty Alleviation through Improve 1, 2016, http://pubs .iclarm.net/wfcms/file/bmz/Zambia\%20governance.pdf. 


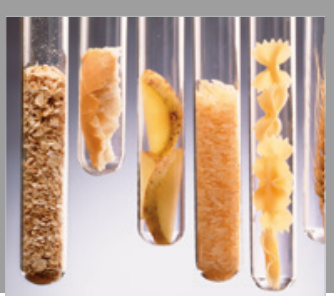

International Journal of Food Science

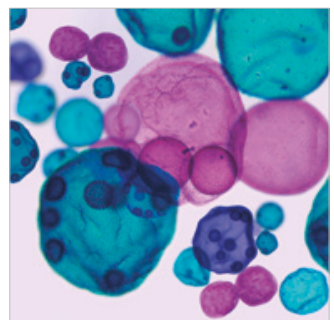

International Journal of Microbiology
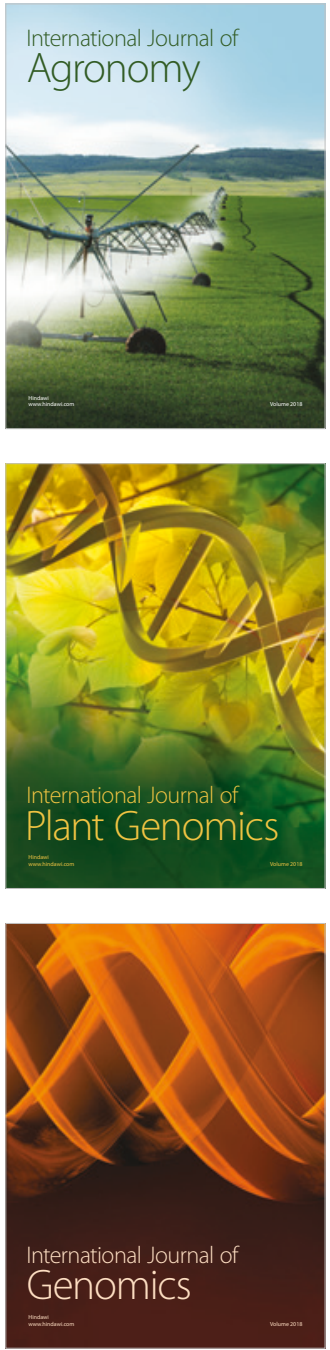

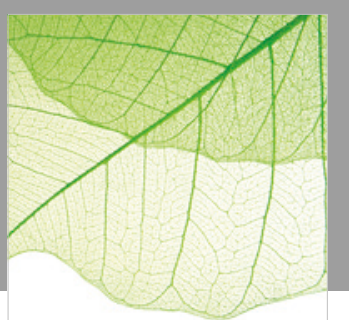

Journal of Botany
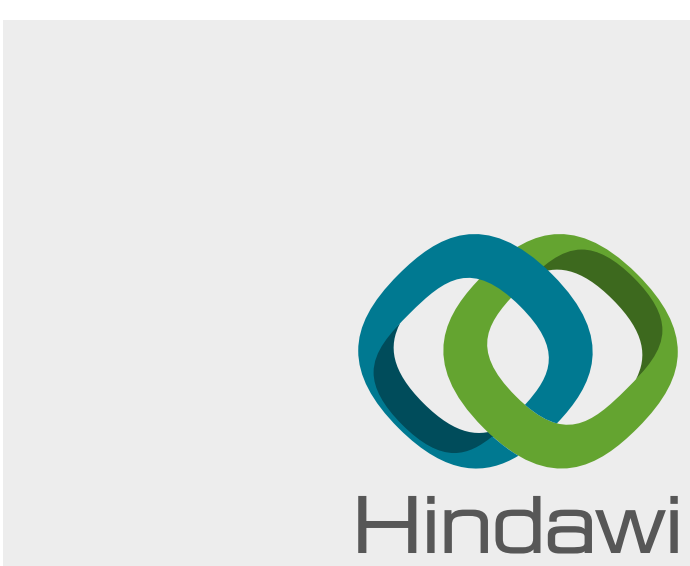

Submit your manuscripts at

www.hindawi.com
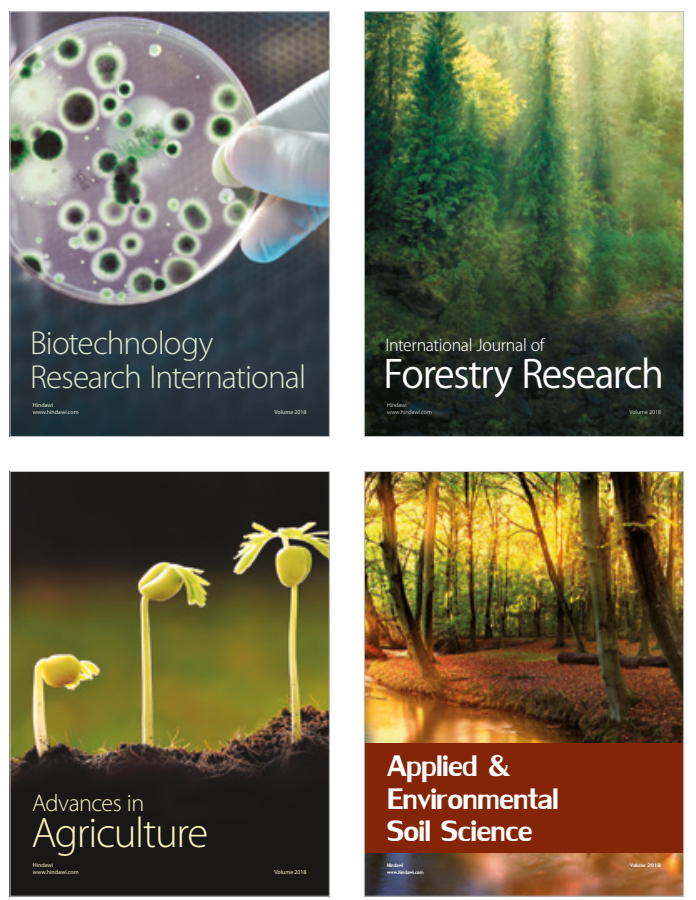

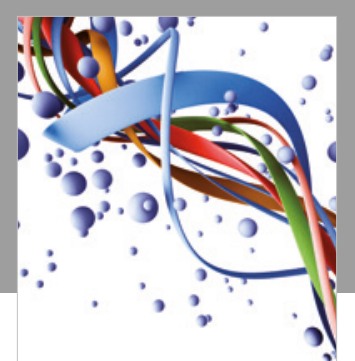

Scientifica

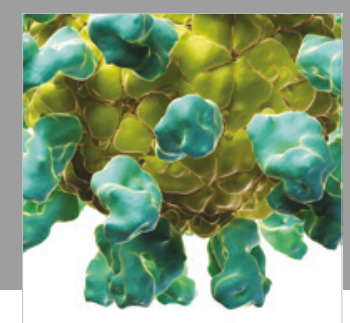

Veterinary Medicine International

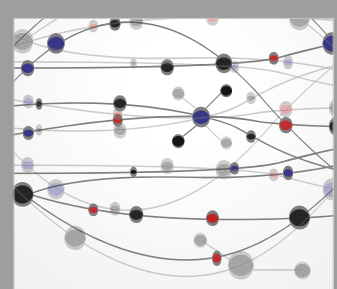

The Scientific World Journal
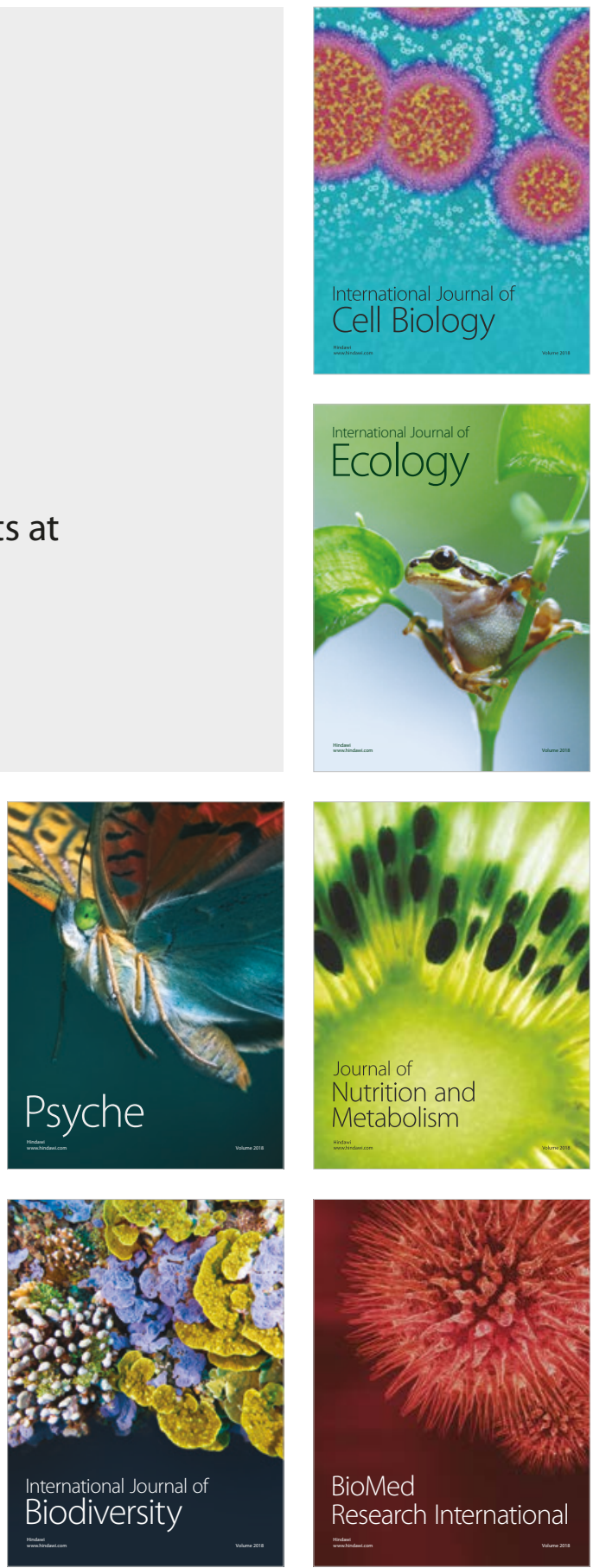